\title{
Cranberries (Vacciniummacrocarpon aiton) in dog nutrition: influence on diet digestibility and palatability and in the course of urinary tract infections
}

[Cranberrys (Vaccinium macrocarpon aiton) na nutrição de cães: influência na digestibilidade e palatabilidade da dieta e no curso de infecções do trato urinário

V.R. Olszewski, T.S. Bastos*, A.S. Komarcheuski, S.G. Oliveira, J.F.G. Warth, A.P. Félix

Universidade Federal do Paraná - Curitiba, PR

\begin{abstract}
The objective was to evaluate the effects of cranberry on blood and urinary parameters of dogs (experiment I), digestibility of nutrients (experiment II), palatability of diet (experiment III) and the influence of cranberry on E. coli UPEC-MRHA fimbriae in vitro (experiment IV). For experiment I and II, ten dogs were fed with diets containing $0 \%$ or $0.4 \%$ cranberry for 30 days. Experiment III compared the diets containing $0 \%$ and $0.4 \%$ cranberry using 16 adult dogs. There were no statistical differences $(\mathrm{P}>0.05)$ in the blood parameters evaluated. Dogs consuming cranberry presented lighter color and appearance of urine, compared to the control group $(\mathrm{P}<0.05)$. The diet containing cranberry showed higher digestibility of dry matter, organic matter, ether extract, higher metabolizable energy $(\mathrm{P}<0.05)$ and reduced fecal sialic acid concentration $(\mathrm{P}<0.05)$ compared to the control diet. There was no influence of cranberry on the formation of fimbriae of $E$. coli UPEC-MRHA. There was a lower intake ratio of the diet containing cranberry $(\mathrm{P}<0.05)$. The inclusion of $0.4 \%$ cranberry increases the digestibility of nutrients and influences the color and appearance of urine of dogs. However, it reduces diet palatability and does not alter the adhesion of $E$. coli UPEC-MRHA in vitro.
\end{abstract}

Keywords: anthocyanidins, blueberry, cystitis, functional diet, nutraceutical, urinary tract infection

\section{RESUMO}

O objetivo foi avaliar os efeitos do cranberry nos parâmetros sanguíneos e urinários de cães (experimento I), na digestibilidade dos nutrientes (experimento II), na palatabilidade da dieta (experimento III) e a influência do cranberry sobre E. coli UPEC-MRHA fimbriae in vitro (experimento IV). Para os experimentos I e II, 10 cães foram alimentados com dietas contendo $0 \%$ ou $0,4 \%$ de cranberry por 30 dias. $O$ experimento III comparou as dietas contendo $0 \%$ e $0,4 \%$ de cranberry usando 16 cães adultos. Não houve diferenças estatísticas $(P>0,05)$ nos parâmetros sanguíneos avaliados. Cães que consumiram cranberry apresentaram cor e aparência mais claras da urina, em comparação com o grupo controle $(P<0,05)$. A dieta contendo cranberry apresentou maior digestibilidade da matéria seca, extrato etéreo, matéria orgânica, maior energia metabolizável $(P<0,05)$ e menor concentração de ácido siálico fecal $(P<0,05)$ comparada à dieta controle. Não houve influência do cranberry na formação de fimbrias de E. coli UPEC-MRHA. Houve uma menor taxa de ingestão da dieta contendo cranberry $(P<0,05)$. A inclusão de 0,4\% de cranberry aumenta a digestibilidade dos nutrientes, influencia a cor e a aparência da urina dos cães. No entanto, reduz a palatabilidade da dieta e não altera a adesão de E. coli UPEC-MRHA in vitro.

Palavras-chave: antocianidinas, alimentação funcional, cistite, mirtilo-vermelho, nutracêutico, infecção urinária

Recebido em 17 de julho de 2019

Aceito em 25 de maio de 2020

*Autor para correspondência (corresponding author)

E-mail: tais.sbastoss@gmail.com 


\section{INTRODUCTION}

The cranberry (Vacciniummacrocarpon aiton) is a native plant from northern hemisphere and is recognized for its therapeutic and prophylactic effects (Catão et al., 2015). Due to scientific evidence on the efficacy of this fruit in preventing and assisting the treatment of lower urinary tract diseases (LUTD) in humans (Olby et al., 2017), research on the effects of the dietary supplementation of cranberry to animals has increased (Mazutti et al., 2012). Its composition includes anthocyanidins, proanthocyanidins type A, catechins, and organic acids (citric, malic, quinic, benzoic and glucuronic acid) (Raz et al., 2004). Anthocyanidins can act on some bacteria, such as Escherichia coli, breaking the cytoplasmic membrane and inhibiting enzyme activity (Gondi et al., 2011).

Proanthocyanidins type A are capable of inhibiting bacterial adhesion to the urinary tract, reducing the risk of infection, as demonstrated in humans (Olby et al., 2017). Cranberry anthocyanidins, proanthocyanidins, cathechins and organic acids have been shown to improve the gutmucus layermorphology, reduce gut inflammation and oxidative stress, and to potentially reshape the gut microbiota ecology, aiding in eubiose in mice (Anhê et al., 2014).

Despite these potential beneficial effects of cranberry on urinary and gastrointestinal tract, it presents a bitter and acidic taste (Jepson et al., 2012), and may negatively impair diet palatability for dogs. Considering the aforementioned and the lack of studies about cranberry in dog nutrition, we aimed to evaluate the effects of dietary supplementation with cranberry on blood and urinary parameters and on the digestibility and palatability of the diet in dogs. In addition, the possible influence of cranberry on E. coli UPEC-MRHA fimbriae in in vitro tests was evaluated.

\section{MATERIAL AND METHODS}

The Ethics Committee on Animal Use at the Agrarian Sciences Sector of the Federal University of Paraná approved all the experimental procedures (protocol number 069/2015). The work was divided in four experiments, being: I) blood and urinary evaluation, II) digestibility and fecal characteristics, III) palatability trial and IV) in vitro test on isolates of E. coli. For experiment I and experiment II ten Beagle dogs (5males and 5 females) at one year of age, weighing an average $11 \pm 0.9 \mathrm{~kg}$ were used. The animals were individually housed in concrete kennels (5m long $\times 2 \mathrm{~m}$ wide) with shelter and solarium.

Two experimental diets were tested, one control, without addition of cranberry and the other including $0.4 \%$ of dried cranberry (Tui Alimentos®, Limeira, São Paulo, Brazil). Cranberry was added on top of a complete extruded commercial dry diet for adult dogs (Table 1). Dogs were divided into two groups of five animals each, one control group and one with cranberry added to the diet. The dogs were fed the experimental diets twice daily (08:00 and $15: 30 \mathrm{hr}$ ) for 30 days in sufficient amounts to meet their energy requirements $\left(\mathrm{kcal} . \mathrm{day}^{-1}=130\right.$ $\mathrm{x}$ body weight $^{0.75}$ ), according to NRC (Nutrient..., 2006) guidelines. Water was offered ad libitum.

Table 1. Analyzed chemical composition of experimental diets based on dry matter $(\%)$

\begin{tabular}{|c|c|c|}
\hline Item & $\begin{array}{c}0 \% \\
\text { cranberry }\end{array}$ & $\begin{array}{c}0.4 \% \\
\text { cranberry }\end{array}$ \\
\hline Dry matter & 92.85 & 92.94 \\
\hline Organic matter & 91.87 & 92.10 \\
\hline Ash & 8.13 & 7.90 \\
\hline Crude protein & 26.89 & 26.25 \\
\hline Crude fiber & 3.72 & 3.91 \\
\hline $\begin{array}{l}\text { Ether extract in acid } \\
\text { hydrolysis }\end{array}$ & 14.15 & 14.34 \\
\hline
\end{tabular}

$0.4 \%$ Cranberry (Vacciniummacrocarpon aiton)

For blood and urinary evaluation (Experiment I), the samples were collected on day 0 (initial) and $31^{\text {st }}$ (final) of the experiment. After local antisepsis with iodinated alcohol, the blood samples were collected by jugular vein puncture through the introduction of the needle (40x12). The animals were fasted for 12 hours and water was available ad libitum. After puncture, the samples were transferred into EDTA tubes, which were identified, refrigerated and taken for analysis.

Three $\mathrm{mL}$ of blood was collected in tubes with the anticoagulant EDTA to analyze the complete blood count. Another $3 \mathrm{~mL}$ of blood was collected without anticoagulant for serum 
analyzes. The parameters evaluated were erythrocytes, hemoglobin, hematocrit, platelets, mean corpuscular volume, total leukocytes, and neutrophils. The hematological analyses were performed using the BC 2800 (Mindray AutoHaematologic Analyser $\left.{ }^{\circledR}\right)$. Cell-count slides were stained using rapid hematological staining technique (diff-quick method).

The urine was collected by the cystocentesis procedure. $10 \mathrm{~mL}$ of urine was collected from each animal for urinalysis and urinary bacterioscopy. Bacterioscopy, urine density and $\mathrm{pH}$ were measured according to Callens and Bartges (2015). The results were classified in a scale of 1 to 3 , being: $1=$ Negative; $2=$ Rare Gram-negative bacilli; and $3=$ Rare Grampositive cocci. Bacterial microbiota was classified as 1 = negative; 2 = discrete; and 3 $=$ moderate. The appearance of urine was scored in a scale of 1 to 3 , being: $1=$ Slightly turbid; $2=$ Turbid; and 3 = Lighter. The urine coloration was classified in a scale of $1=$ citrus yellow to $2=$ light yellow. The scores were evaluated by the same researcher.

The digestibility and fecal characteristics trial (Experiment II) followed the recommendations of AAFCO (Dog..., 2008). The experimental period latest 25 days of adaptation to the diets, followed by five days of total fecal collection. Feces were collected twice daily, weighed and frozen $\left(-14^{\circ} \mathrm{C}\right)$ until analyzes. After the collection period, the feces were thawed, homogenized, and dried in a forced air ventilation oven (320-S; Fanem) at $65^{\circ} \mathrm{C}$ for $48 \mathrm{hr}$. After drying, feces and diets were ground to $1-\mathrm{mm}$ sieve in a Willey hammermill (Arthur H. Thomas Co.) and analyzed according to AOAC (Official..., 1995) standards for dry matter (DM, method 934.01), ash (method 942.05), crude protein (CP, method 954.01), and acid-hydrolyzed fat (EE, method 954.02).

Organic matter $(\mathrm{OM})$ was calculated by the difference $(\mathrm{OM}=\mathrm{DM}-\mathrm{ash})$. Gross energy (GE) was determined using a calorimetric pump (Parr Instrument Co., model 1261, moline, IL, USA). For analysis of sialic acid, feces were lyophilized (Alpha 1-4 LO plus; Christ, Osterode Am Hans) and the analysis was done according to Jourdian et al., (1971). Based on the laboratory results, the apparent total tract digestibility (ADC) coefficients and the diet's metabolizable energy
(ME) were calculated according to the AAFCO (Dog..., 2008):

$\mathrm{ADC} \%=[(\mathrm{g}$ of nutrient intake $-\mathrm{g}$ of nutrient excretion $) / g$ of nutrient intake] $\times 100$.

$\operatorname{ME}(\mathrm{kcal} / \mathrm{g})=\{\mathrm{kcal} / \mathrm{g}$ GE intake $-\mathrm{kcal} / \mathrm{g}$ GE fecal excretion $-[$ (g CP intake $-\mathrm{g} \mathrm{CP}$.

The fecal $\mathrm{pH}$ and ammonia were evaluated in fresh feces (maximum 15minutes after defecation). Fecal $\mathrm{pH}$ was measured in $3 \mathrm{~g}$ of fresh feces and $30 \mathrm{~mL}$ of distilled water with a digital $\mathrm{pH}$ meter (331, Politeste Instrumentos de Teste LTDA, Brazil). The concentration of ammonia in feces was determined according to the method described by Félix et al. (2013). The fecal consistency was evaluated in scores from 1 to 5, according to Carciofi (2009): 1- watery stools; 2- soft and unshaped feces; 3- soft, shaped and moist feces; 4 - shaped feces and 5 well shaped, hard and dry feces.

In the experiment III, 16 adult Beagle dogs (8males and 8 females) with one year of age, with average body weight of $10.5 \pm 1.8 \mathrm{~kg}$ were used, weighing an average $11 \pm 0.9 \mathrm{~kg}$. The animals were individually housed in concrete kennels $(5 \mathrm{~m}$ long $\times 2 \mathrm{~m}$ wide) with shelter and solarium. Palatability was measured using a 2bowl test comparing the diets in pairs: control ( $0 \%$ cranberry) vs. test diet $(0.4 \%$ cranberry) The two tested diets were simultaneously offered in two identical bowls once daily (08:00) to the dogs for a period of 30minutes for three consecutive days. The position of the bowls was changed daily in order to prevent the conditioning of feeding always at the same location. The food offered and the leftovers were quantified to calculate the intake ratio (IR): intake of diet A or B (g)/total intake of diets A + $\mathrm{B}(\mathrm{g})$.

In Experiment IV, two E. coli isolates (EC-1 and EC-2) were used in hemagglutination tests. The strains identified as HAMR collected from LABMICRO bacteriotheca of the Department of Veterinary medicine, Federal University of Paraná (UFPR), were originally isolated of pure cultures from cases of bacterial cystitis infection in dogs, attended at the Veterinary Hospital of UFPR. The expression of fimbriae adhesins in the pathogens EC-1 and EC-2 was verified by the technique of hemagglutination in a slide, described by Evans et al. (1981). The strains 
were classified as UPEC HAMR, due to the same intensity of hemagglutination in the presence and absence of $1 \%$ D-Mannose. The bacterial growth was obtained in brain-heart infusion agar supplemented with $5 \%$ of blood, at $\mathrm{pH} 7.2$

A stock solution with $25 \%$ cranberry extract was obtained by adding $25 \mathrm{~g}$ of cranberry powder in $100 \mathrm{~mL}$ of physiological solution. After mixing, the solution was filtered on a $0.65 \mu$ cellulose acetate membrane, which resulted in a sterile extract to be added in culture medium called BHI Agar supplemented or not with sheep's blood at $\mathrm{pH} 5.0$ and $\mathrm{pH}$ 7.2. The influence of the cranberry extract on the production of HAMR fimbriae was verified using the following culture mediums: 1-agar BHI supplemented with 5\% sheep blood solution at $\mathrm{pH} 7.2 ; 2$-agar BHI supplemented with 5\% sheep blood solution at $\mathrm{pH}$ 5.0; 3-agar BHI supplemented with 5\% solution of cranberry extract at $\mathrm{pH} 7.2$ filtrated at $0.65 \mu$ cellulose acetate membrane; 4-agar BHI supplemented with 5\% solution of cranberry extract at $\mathrm{pH} 5.0$ filtrated at $0.65 \mu$ cellulose acetate membrane; 5-agar BHI supplemented with $5 \%$ cranberry extract and 5\% sheep blood at $\mathrm{pH} 7.2$; and 6-agar BHI supplemented with 5\% cranberry extract and 5\% sheep blood at $\mathrm{pH} 5.0$.

The two isolates of E. coli EC-1 and EC-2 were seeded on the surface of the six-culture media at $37^{\circ} \mathrm{C}$ for $48-72$ hours to obtain bacterial colonies to be submitted to the hemagglutination test, as well as for the fimbriae formation. The expression of fimbriae adhesins in pathogens EC-1 and EC-2 seeded in mediums 1 to 6 was verified by the hemagglutination technique described by Evans et $a$. (1981).

For the statistical analyzes, all data were first submitted to the normality test of Shapiro Wilk $(\mathrm{P}<0.05)$. The parametric urine and blood data were submitted to Analyzes of variance, considering a completely randomized design in a split-plot arrangement (plot $=$ diets and sub-plot = periods), totaling five replicates per treatment. Digestibility, fecal characteristics and palatability data were analyzed according to a completely randomized design by the Student's t-test $(\mathrm{P}<0.05)$, with 5 replicates per treatment for digestibility and fecal characteristics and 48 for palatability (16 dogs x 3 days). The nonparametric data were analyzed by the KruskalWallis test $(\mathrm{P}<0.05)$.

\section{RESULTS}

All animals fully consumed the diets offered and episodes of vomiting and diarrhea were not observed during the experiment. Dogs presented higher leukocyte concentration $(\mathrm{P}<0.05)$ in the beginning of experimental period (day 0 ), in relation to the final period ( $31^{\text {st }}$ day). However, diet did not alter the leukocyte concentration $(\mathrm{P}>0.05)$ of dogs. The other blood parameters evaluated were within normal range, without statistical variation $(\mathrm{P}>0.05$, Table 2$)$.

Table 2. Averages of blood parameters of dogs fed diets without and with $0.4 \%$ cranberry (Vacciniummacrocarpon aiton)

\begin{tabular}{|c|c|c|c|c|c|c|c|c|}
\hline \multirow[b]{2}{*}{ Item } & \multicolumn{2}{|l|}{ Day 0} & \multicolumn{2}{|l|}{ Day $31^{\text {st }}$} & \multirow[b]{2}{*}{ SEM } & \multicolumn{3}{|l|}{$\mathrm{P}$} \\
\hline & $\begin{array}{l}0 \% \\
\text { cranberry }\end{array}$ & $\begin{array}{l}0.4 \% \\
\text { cranberry }\end{array}$ & $\begin{array}{l}0 \% \\
\text { cranberry }\end{array}$ & $\begin{array}{l}0.4 \% \\
\text { cranberry }\end{array}$ & & $\begin{array}{l}\text { Diet } \\
\text { (D) }\end{array}$ & $\begin{array}{l}\text { Period } \\
\text { (P) }\end{array}$ & $\mathrm{D} \times \mathrm{P}$ \\
\hline Erythrocytes $(\mathrm{mi} / \mu \mathrm{L})$ & 6.3 & 6.6 & 6.8 & 6.4 & 0.092 & 0.631 & 0.453 & 0.104 \\
\hline Hematocrit (\%) & 43.4 & 45.2 & 45.4 & 44.2 & 0.650 & 0.709 & 0.682 & 0.352 \\
\hline Hemoglobin (g/dL) & 14.2 & 15.1 & 15.5 & 15.2 & 0.788 & 0.409 & 0.206 & 0.222 \\
\hline MCV (u3) & 68.0 & 68.3 & 66.2 & 68.6 & 0.565 & 0.364 & 0.034 & 0.415 \\
\hline Leukocytes $\left(\mathrm{mm}^{3}\right)$ & 20.5 & 16.6 & 14.9 & 13.8 & 1073.4 & 0.364 & 0.034 & 0.415 \\
\hline Neutrophils (\%) & 71.8 & 65.4 & 70.4 & 74.0 & 1.886 & 0.751 & 0.378 & 0.231 \\
\hline Neutrophils $\left(/ \mathrm{mm}^{3}\right)$ & 15.2 & 10.9 & 10.5 & 10.2 & 1020.7 & 0.339 & 0.194 & 0.323 \\
\hline Platelets $\left(/ \mathrm{mm}^{3}\right)$ & 465.0 & 456.4 & 440.6 & 394.6 & 14.84 & 0.308 & 0.583 & 0.418 \\
\hline
\end{tabular}

$\mathrm{MCV}$-mean corpuscular volume; SEM - standard error of the mean.

Dogs that consumed cranberry presented lighter color and appearance of urine after 30 days of feeding, when compared to the control period (day 0) and to the dogs from the control group $(\mathrm{P}<0.05$, Table 3$)$. The other urinary parameters evaluated such as density, bacterial flora and $\mathrm{pH}$ were within normality for dogs and did not differ between periods and treatments $(\mathrm{P}>0.05)$. The inclusion of cranberry in the diet increased $(\mathrm{P}<0.05)$ the digestibility of DM, OM, EE and E 
(Table 4). There was no difference in the fecal characteristics of dogs $(\mathrm{P}>0.05)$. However, the inclusion of cranberry in the diet decreased fecal sialic acid concentration $(\mathrm{P}<0.05$, Table 4$)$. The intake ratio was lower $(\mathrm{P}<0.05)$ for the diet with inclusion of $0.4 \%$ cranberry, when compared to the control diet (Table 5). The in vitro trial did not demonstrate a reduction in the proliferation of E. coli, or in red blood cell hemagglutination when in contact with cranberry. It was observed in all media culture the visible formation of islets of red blood cells and bacterial aggregation to them at $\mathrm{pH} 7.2$ and less intensely at $\mathrm{pH} 5.0$ (Table 6).

Table 3. Medians and percentiles (p25; p75) of the urinalysis of dogs fed diets with or without $0.4 \%$ cranberry (Vacciniummacrocarpon aiton)

\begin{tabular}{lcccccc}
\multirow{2}{*}{ Item } & \multicolumn{2}{c}{ Day 0} & \multicolumn{2}{c}{ Day $31^{\text {st }}$} & \multirow{2}{*}{$\mathrm{P}$} \\
\cline { 2 - 5 } & $0 \%$ cranberry & $0.4 \%$ cranberry & $0 \%$ cranberry & $0.4 \%$ cranberry & \\
\hline Aspect & $1(1 ; 1)^{\mathrm{b}}$ & $2(1 ; 3)^{\mathrm{b}}$ & $2(1 ; 3)^{\mathrm{b}}$ & $3(3 ; 3)^{\mathrm{a}}$ & 0.005 \\
Bacterio. & $1(1 ; 1)$ & $1(1 ; 3)$ & $1(1 ; 1.5)$ & $1(1 ; 2)$ & 0.483 \\
Coloring & $1(1 ; 1)^{\mathrm{b}}$ & $1(1 ; 1)^{\mathrm{b}}$ & $1(1 ; 1)^{\mathrm{b}}$ & $2(1 ; 2)^{\mathrm{a}}$ & 0.006 \\
Density & $1020(1015 ; 1020)$ & $1020(1020 ; 1020)$ & $1020(1017 ; 1020)$ & $1020(1017 ; 1020)$ & 0.797 \\
Microbiota & $2(1.5 ; 2.5)$ & $2(1 ; 2)$ & $2(2 ; 2)$ & $2(2 ; 2)$ & 0.404 \\
pH & $5(5 ; 6)$ & $5(5 ; 5)$ & $5(5 ; 5.5)$ & $5(5 ; 5.5)$ & 0.797 \\
\hline
\end{tabular}

*Bacterio. - bacterioscopy: 1 = Negative, 2 = Rare Gram-negative bacilli, 3 = Rare Gram-positive cocci; Density (g/L); Aspect: 1 = Slightly turbid, 2 = Turbid, 3 = Lighter; Coloration: 1 = citrus yellow, 2 = light yellow; microbiota: 1 = negative, 2 = discrete, 3 =moderate. ${ }^{\mathrm{a}, \mathrm{b}}$ Different letters indicate difference by the Kruskall-Wallis test.

Table 4. Apparent digestibility coefficients (ADC, \%) and metabolizable energy (ME, $\mathrm{kcal} / \mathrm{kg}$ ) of diets and fecal characteristics of dogs fed diets without and with $0.4 \%$ cranberry (Vacciniummacrocarpon aiton)

\begin{tabular}{lcccc}
\hline \multicolumn{1}{c}{ Item } & 0\% cranberry & $0.4 \%$ cranberry & SEM & P \\
\hline ADC & & & & 0.87 \\
Dry matter & 75.4 & 79.1 & 0.61 & 0.015 \\
Organic matter & 81.7 & 84.5 & 0.45 & 0.012 \\
Crude protein & 80.9 & 80.3 & 0.86 & 0.470 \\
Ether extract & 87.8 & 90.9 & 25.50 & 0.017 \\
mE & 3885.7 & 3987.5 & & 0.049 \\
Fecal characteristics & & & 0.73 & 0.503 \\
FDM & 39.4 & 40.5 & 0.02 & 0.012 \\
Sialic acid (umol /g) & 3.9 & 3.5 & - & 0.274 \\
Score & 3.7 & 3.8 & - & 0.630 \\
pH & 7.0 & 7.3 & - & 0.298 \\
Ammonia (\%) & 0.1 & 0.1 &
\end{tabular}

SEM: standard error of the mean. $\mathrm{P}<0.05$ for means analyzed by the t-Student test. Except for fecal score, $\mathrm{pH}$ and ammonia, which were analyzed by Kruskal Wallis test $(\mathrm{P}<0.05)$ and presented as medians. Fecal score: $1=$ liquid stool to $5=$ dry stool.

Table 5. Intake ratio (IR, mean \pm standard error) of diets without (A) and with $0.4 \%$ cranberry (Vacciniummacrocarpon aiton) (B) in dogs

\begin{tabular}{lcc}
\hline \multicolumn{1}{c}{ Diet A vs. B } & IR of diet A & P \\
\hline $0 \%$ vs. $0.4 \%$ Cranberry & $0.59 \pm 0.42 *$ & 0.042 \\
\hline *P value $<0.05$ by Student $t$ test & &
\end{tabular}


Table 6. Expression of E. coli UPEC-HAMR (mannose resistant) samples isolated from dogs by hemagglutination test

\begin{tabular}{lcccccc}
\multirow{2}{*}{ E. coli strains } & \multicolumn{7}{c}{ Hemmaglutination medium } \\
\cline { 2 - 7 } & BA 7.2 & BA 5.0 & CA 7.2 & CA 5.0 & CBA 7.2 & CBA 5.0 \\
\hline EC II-1 & + & + & + & + & + & $(+)$ \\
EC II-2 & + & + & + & + & + & $(+)$ \\
\hline
\end{tabular}

BA: $7.2=$ blood agar at $\mathrm{pH} 7.2$; BA $5.0=$ blood agar at $\mathrm{pH} 5.0 ; \mathrm{CA} 7.2=$ cranberry agar at $\mathrm{pH} 7.2$; CA $5.0=$ cranberry agar at $\mathrm{pH} 5.0$; CBA $7.2=$ cranberry and blood agar at $\mathrm{pH} 7.2$; CBA $5.0=$ cranberry and blood agar at $\mathrm{pH}$ 5.0. +: Strong hemagglutination(+): Weak hemagglutination

\section{DISCUSSION}

This study evaluated the effects of dietary supplementation of cranberry on blood and urinary parameters and on diet digestibility and palatability for dogs. Although cranberry did not affect any evaluated blood parameters, a slight increase $\left(\right.$ mean $\left.=18.510 \pm 1073.4 / \mathrm{m}^{3}\right)$ above normal range $\left(6000\right.$ to $18.000 / \mathrm{m}^{3}$, Pereira et al., 2019) in leukocytes at the beginning of the experiment was observed in dogs, regardless of dietary treatments. There are numerous factors that can cause the increase in leukocytes in dogs, which can be physiological, reactive or proliferative (Lopes et al., 2008). In the present study, the variation in the number of leukocytes observed can possibly be classified as reactive, due to the vaccination carried out a few days before the experimental period (Pereira et al., 2019). Furthermore, the dogs did not present any clinical sign during the experiment. Considering that, it is possible that the addition of $0.4 \%$ cranberry in diet is safe to be consumed by dogs, but more studies evaluating this consumption for longer periods of time are warranted.

Regarding the urinary results, the lack of differences on the presence of bacteria in urine between groups indicates that cranberry possibly doesn't have important effects on microorganisms already present in the urinary tract of healthy dogs without LUTD. In $90 \%$ of cases, urinary tract infections are caused by $E$. coli (Moura and Fernandes, 2010). Although, other Gram-negative microorganisms may also be responsible for causing the infection, such as the genders Klebsiella, Enterobacter, Pseudomonas, Enterococci and Staphylococci (Sato et al., 2005). For animals with LUTD, it is expected to find urine with alkaline $\mathrm{pH}$, which favors these bacteria growth and adhesion (Mazutti et al., 2012). From the collected samples, the urinary $\mathrm{pH}$ did not present statistical variation and the results obtained were within the normal range, from 5 to 8 (Feitosa, 2008). Therefore, in the present study apparently cranberry and its components did not act in the acidification of the urine of healthy dogs.

Despite the lack of effects on urinary $\mathrm{pH}$ and bacteria composition of dogs, the dietary supplementation with cranberry changed the urine color from turbid and yellow citrus (control group) to lighter yellow color (cranberry group). This change in urine coloration is within the normality standard for dogs (Feitosa, 2008), but can indicate a preventive effect of cranberry on urinary tract infections. Turbid urine is a characteristic of urinary sedimentation, which may occur by deposition of protein, epithelial cells, bacteria, crystals, and other substances, leading to urinary tract diseases (Mazutti et al., 2012).

No studies were found about the dietary supplementation of cranberry for dogs, being difficult to determine the effective dietary concentration to animals. Therefore, further studies are needed to determine the effective dietary concentration of cranberry, especially in dogs diagnosed with LUTD.

Although it was not expected, cranberry showed to improve diet digestibility in dogs. Due to this result, the fecal sialic acid concentration was evaluated. This analyzes can provide more information about mucus production and intestinal health of animals (Pirgozliev et al., 2005). According to Jourdian et al. (1971), the sialic acid is one of the main components of mucin, produced by goblets cells on mucosa layer, and released into the intestinal lumen in response to toxins or other harmful agents, generally associated to pathogens, bacterial infections, and osmotic fragility. It is not clear in the literature how the excretion of this acid affects animal nutrition and there is still little 
information on the measurement of sialic acid in dog feces.

But it is already known that excessive secretion of this acid, besides increasing the endogenous losses of nutrients, also impairs their absorption by the barrier formed between digesta and enzymes (Pirgozliev et al., 2005). In the present study, the dogs were clinically healthy, without apparent enteropathies, but even in this case, cranberry supplementation reduced sialic acid concentration. It is possible that cranberry anthocyanidins, proanthocyanidins, cathechins and organic acids improved intestinal functionality. These substances have been shown to improve the gut mucus layermorphology, reduce gut inflammation and oxidative stress, and to positively change gut microbiota in mice (Anhê et al., 2014).

Particularly proanthocyanidins type A present anti-adherence properties to gram-negative bacteria fimbriae, as $E$. coli (Howell et al., 2005), reducing its colonization on intestinal mucosa layer. This fact was shown in in vivo and in vitro studies with cranberry extract (Davey et al., 2008; Johnson et al., 2008; Omay and Tufenkji, 2011). However, we did not find any differences on in vitro test of $E$. coli adherence in mediums with or without cranberry solution, maybe due to other interactions that occur on the gastrointestinal tract and on the cranberry concentration used.

Cranberry has a significant amount of benzoic acid (5g per $\mathrm{kg}$ of fruit), but there are still few studies on the presence and action of this acid in this fruit and what would be the mechanism of action of cranberry components in the body of the animals. Despite the acidifying effects and reduced ammonia excretion reported by $\mathrm{Mroz}$ (2005), in the present study, cranberry did not change the consistency, fecal $\mathrm{pH}$ and ammonia of dogs. There are few studies on $\mathrm{dog}$ food preferences, but it has already been described by Félix et al., (2010) that dogs have high preference for meat and sugar, and food additives with bitter tastes may become unpalatable for these animals. The cranberry fruit is not palatable to humans, presenting bitter and acidic taste. Still, the products marketed to humans with cranberry are usually sweetened to make their consumption more attractive (Jepson et al., 2012).
The low palatability of cranberry negatively influenced diet preference in dogs, which preferred the diet without the inclusion of this fruit. Nevertheless, dogs that received exclusively the diet containing cranberry for 30 days did not refuse to eat, presenting total consumption of the diet offered. Another factor influencing diet preference for dogs was the physical form of the additive, which was offered in powdered form, sprayed on the diet. It is known that dogs generally prefer moist or semimoist foods, with an abundance of proteins and lipids in their composition and extruded dry diets, poor in lipids and proteins are less accepted (Felix et al., 2013). The product used contained only cranberry extract and carbohydrates, with low amounts of proteins and lipids. Considering that, it is important to consider different forms of cranberry inclusion in the diet of dogs, such as their inclusion in the dough, before extrusion.

\section{CONCLUSIONS}

The inclusion of $0.4 \%$ cranberry in the diet of healthy $\operatorname{dog}$ s for 30 days alters the appearance and color of urine, making it clearer without altering other urinary and blood parameters or the adhesion capacity of E. coli HAMR in vitro. Furthermore, the inclusion of $0.4 \%$ cranberry increases the digestibility and metabolizable energy of the diet, without altering the fecal characteristics of the dogs and decreases the production of sialic acid in the intestine. However, it reduces diet intake due to palatability impairment.

\section{ACKNOWLEDGEMENTS}

We would to thank for Leonardo Gaspareto dos Santos and Carolina Teochmann for helping with urine collection.

\section{REFERENCES}

ANHÊ, F.F.; ROY, D.; PILON, G. et al. A polyphenol-rich cranberry extract protects from diet-induced obesity, insulin resistance and intestinal inflammation in association with increased Akkermansia spp. population in the gutmicrobiota of mice. Gut, v.64, p.872-883, 2014. 
CALLENS, A.J.; BARTGES, J.W. Urinalysis. Vet. Clin. N. Am. Small Anim. Pract., v.45, p.621637, 2015

CARCIOFI, A.; TESHIMA, E.; BAZOLLI, R.S. et al. Qualidade e digestibilidade de alimentos comerciais de diferentes segmentos de mercado para cães adultos. Rev. Bras. Saúde Prod. Anim., v.10, p.489-500, 2009.

CATÃO, R.M.R.; NUNES, L.E.; VIANA, A.P.P. et al. Atividade antibacteriana e efeito interativo in vitro de um produto a base de cranberry sobre Escherichia coli. Rev. Ciênc. Farm. Basic. Aplic., v.35, p.723-729, 2015.

DAVEY, M.; LIU, X.; UKAI, T. et al. Bacterial fimbriae stimulate proinflammatory activation in the endothelium through distinct TLRs. $J$. Immunol., v.180, p.2187-2195, 2008.

DOG and cat nutrient profiles official publications of the Association of American Feed Control Officials Incorporated. Oxford: AAFCO, 2008.

EVANS, J.; EVANS, D.G.; YOUNG, L.S.; PITT, J. Hemagglutination typing of Escherichia coli: definition of seen hemagglutions types. J. Clin. Microbiol., v.12, p.235-242, 1981.

FEITOSA, F.L.F. Semiologia veterinária: a arte do diagnóstico: cães, gatos, equinos, ruminantes e silvestres. 2.ed. São Paulo: Roca, 2008. p.407.

FÉLIX, A.P.; MAIORKA, A.; OLIVEIRA, S.G. Fatores que interferem no consumo de alimentos em cães e gatos. In: VIEIRA, S. Consumo $e$ preferência alimentar de animais domésticos. Londrina: Phytobiotics, 2010. p.162-199.

FÉLIX, A.P.; ZANATTA C.P.; BRITO, C.B.M.; SÁ FORTES, C.M.L. et al. Digestibility andmetabolizable energy of raw soyamanufactured with different processing treatments and fed to adult dogs and puppies. $J$. Anim., v.91, p.2794-2801, 2013.

GONDIM, B.L.C.; VIEIRA, T.I.; CUNHA, SANTIAGO B.M.; VALENÇA A.M.G. Atividade antimicrobiana de produtos naturais frente a bactérias formadoras do biofilme dentário. Pesqui. Bras. Odontoped. Clin. Integr., v.11, p.123-127, 2011.
HOWELL, A.B.; REED, J.D.; KRUEGER, C.G. et al. A-type cranberry proanthocyanidins and uropathogenic bacterial anti-adhesion activity. Phytochemistry, v.66, p.2281-2291, 2005.

JEPSON, R.G.; WILLIAMS, G.; CRAIG, J.C. Cranberries for preventing urinary tract infections. Cochrane Database Syst. Rev., n.10, 2012.

JOHNSON, J.R.; BAOCHUAN, L.; DINDERMAN, M.A. et al. Impact of cranberry on Escherichia Coli cellular surface characteristics. Biophys. Res. Commun., v.377, p.992-994. 2008.

JOURDIAN, G.W.; DEAN, L.; ROSEMAN, S. Um método de periodato-resorcinol para a estimativa quantitativa de ácidos siálicos livres e seus glicosídeos. J. Biol. Chem., v.246, p.430435, 1971.

LOPES, S.T.A.; BIONDO, A.W.; SANTOS, A.P. Manual de patologia clínica veterinária. 3.ed. Santa Maria: Universidade Federal de Santa Maria, 2008. 38p.

MAZUTTI, K.; ALBERTON, G.C.; FERREIRA, F.M. et al. Efeito do extrato de Oxicoco no tratamento de infecções do trato urinário em porcas. Arch. Vet. Sci., v.17, p.1-9, 2012.

MOURA, L.B.; FERNANDES, M. A incidência de infecções urinárias causadas por E. coli. Olhar Cient., v.1, p.411-426, 2010.

MROZ, Z. Organic acids as potential alternatives to antibiotic growth promoters for pigs. $A d v$. Pork Prod., v.6, p.169-182, 2005.

NUTRIENT requirements of dogs and cats. Rev. Washington: National Academies Press, 2006.

OFFICIAL methods of analysis. 16.ed. Virginia: AOAC, 1995.

OLBY, N.J.; VADEN, S.L.; WILLIAMS, K. et $a l$. Cranberry extract and bacteriuria in dogs. $J$. Vet. Intern. Med., v.31, p.60-68, 2017.

OMAY, C.; TUFENKJI, N. The swarmingmotility of pseudomonas aeruginosa is blocked by cranberry proanthocyanidins and other tannin-containingmaterials. Am. Soc. Microbiol., v.77, p.3061-3067, 2011. 


\section{Cranberries...}

PEREIRA, M.; VALÉRIO-BOLAS, A.; SARAIVA-MARQUES, C. et al. Development of dog immune system: from in uterus to elderly. Vet. Sci., v.6, p.83, 2019.

PIRGOZLIEV, V.; SHANMUGAVELU, S.; ACAMOVIC, T. Effect of the method of drying on the concentration of sialic acid in poultry excreta. Poult. Sci. Assoc., p.536-538, 2005.
RAZ, R.; CHAZAN, B.; DAN, M. Cranberry juice and urinary tract infection. Clin. Infect. Dis., v.38, p.1413-1419, 2004.

SATO, F.A.; SVIDZINSKI, A.E.; CONSOLARO, M.; BOER, C.G. Nitrito urinário e infecção do trato urinário por cocos grampositivos. J. Bras. Patol. Med. Lab., v.41, p.397404, 2005. 